
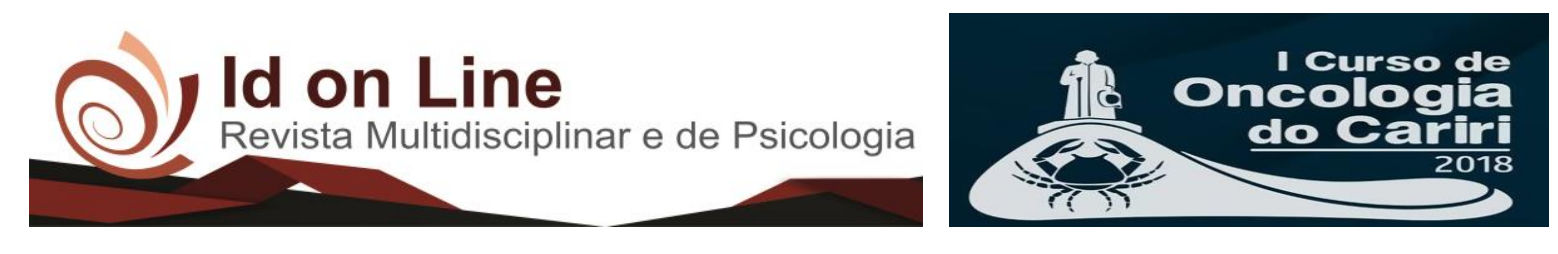

Resumo

\title{
PLASMOCITOMA E MIELOMA MÚLTIPLO: UMA RELAÇÃO QUE PRECISA SER ESTUDADA
}

\author{
Maria Iara Alves Araújo ${ }^{1}$, Brenda Lacerda da Silva ${ }^{l}$, Francisco Allyson Lopes Xavier' \\ Itamar Alves Araújo'.
}

Introdução: A neoplasia de células plasmáticas surge como uma lesão isolada (plasmocitoma) ou como múltiplas lesões (mieloma múltiplo); sendo, portanto, caracterizada por uma generalização autônoma e irreversível de plasmócitos. Ademais, sabe-se que o plasmocitoma é um tumor maligno, composto por plasmócitos com diferentes graus de maturação, histologicamente idênticos aos observados no mieloma múltiplo. Objetivo: Elucidar a possível relação entre plasmocitoma e mieloma múltiplo. Método: Trata-se de uma revisão sistemática com base em matérias publicadas em artigos disponíveis nas bases de dados SciELO e LILACS. Os descritores empregados na busca (em português e inglês) foram: mieloma múltiplo, plasmocitoma, sendo pesquisados no DeCS. Os critérios de inclusão foram: estudos sobre a relação entre plasmocitoma e mieloma múltiplo, tipos de plasmocitomas; e os de exclusão: artigos direcionados para outros tipos neoplasias ou para outros temas, e estudos que não fossem com humanos. Ademais, apenas artigos publicados a partir do ano 2000 foram relevantes para a extração de dados. Foram encontrados 380 artigos. Desse total, foram apurados 4 com base nos critérios de inclusão e exclusão. Resultado: A partir das informações encontradas, analisou-se que o plasmocitoma é classificado em três subtipos. Dentre eles, o mais comum é o mieloma múltiplo, que geralmente é uma doença disseminada e caracterizada por proteína $\mathrm{M}$ anormal. Ainda não é conhecido o motivo pelo qual se desenvolvem o mieloma múltiplo e o plasmocitoma; mas, possivelmente, está relacionado às distinções nas moléculas de adesão celular ou nas categorias de expressão dos receptores das células malignas. Conclusão: Com as análises, pode-se perceber que a relação entre o mieloma múltiplo e o plasmocitoma, apesar de ser notória, é pouco conhecida no que tange seus aspectos fisiopatológicos; portanto, precisa ser estudada com o intuito de melhorar o prognóstico e a qualidade de vida de indivíduos portadores dessas pragmáticas doenças.

Palavras-chave: Plasmocitoma, Mieloma múltiplo, Neoplasia.

\footnotetext{
${ }^{1}$ Discente da Faculdade de Medicina Estácio de Juazeiro do Norte;

Autor correspondente: iara_aaraujo@hotmail.com.
}

35 Id on Line Rev. Mult. Psic. V.12, N. 40. 2018 - ISSN 1981-1179 EDIÇÃO ESPECIAL: I CURSO DE ONCOLOGIA DO CARIRI / II JORNADA DE PESQUISA QUANTI-QUALITATIVA EM ONCOLOGIA. JUAZEIRO DO NORTE, 05 A 10 DE MARÇO DE 2018. Edição eletrônica em http://idonline.emnuvens.com.br/id 